\title{
Acute Toxicity, Behavioural Changes and Histopathological Effect of Paraquat Dichloride on Tissues of Catfish (Clarias Gariepinus)
}

\author{
Ladipo M. K. \\ Department of Polymer and Textile Technology \\ Yaba College of Technology, Lagos \\ P.M.B.2011, Yaba Lagos, Nigeria \\ E-mail: kudiladipo@yahoo.ca \\ Doherty V. F. (Corresponding author) \\ Department of Biological Sciences \\ Yaba College of Technology, Lagos \\ P.M.B.2011,Yaba Lagos,Nigeria
}

Tel: 234-803-310-7074 E-mail: funmilayodoherty@yahoo.co.uk

\author{
Oyebadejo S. A. \\ Histology Unit, Department of Anatomy \\ College of Medicine, University of Lagos \\ E-mail: samson_oyebadejo@yahoo.ca
}

Received: January 05, 2011 Accepted: January 24, 2011 doi:10.5539/ijb.v3n2p67

\begin{abstract}
The toxicity of Paraquat dichloride, a herbicide, was investigated with emphasis on histopathological effects of African Catfish (Clarias gariepinus) juvenile. The fishes were exposed to 0, 20,60, 80, $110 \mathrm{mg} / \mathrm{l}$ of Paraquat dichloride ., The lethal concentration $\left(\mathrm{LC}_{50}\right.$ ) value of Paraquat dichloride was $1.75 \mathrm{mg} / \mathrm{l}$ for $96 \mathrm{~h}$ of exposure. Histopathology of the organs after $96 \mathrm{hr}$ exposure revealed cell proliferation, lamellar fusion, lamellar cell hyperplasia, and epithelial lifting. In the liver, there was vacuolation of hepatocytes and necrosis. The changes in these tissues occur predominantly in the $96 \mathrm{hr}$ exposure. Respiratory stress, erratic swimming and instant death of fish were observed in exposed fish, which varied with the concentration of the toxicant. Paraquat dichloride is highly toxic to Clarias gariepinus, therefore its use near fish farms or in areas close to aquatic bodies should not be encouraged.
\end{abstract}

Keywords: Paraquat dichloride, Histopathology, African catfish, Hyperplasia

\section{Introduction}

Herbicides are widely used for the control of water plants which may impede the flow of aquatic life and may contribute long term effects in the environment (Annue et al., 1994). The constant flow of agricultural effluents into fresh water often leads to a variety of pollutant accumulation, which becomes apparent when considering toxic pollution (Mason, 1991). Pesticide surface runoff into rivers and streams can be highly lethal to aquatic life. Herbicides can accumulate in bodies of water to levels that kill off zooplankton, the main source of food for young fish.

Accidental spills and dumpsites also account for a part of the environmental pesticide input. In contrast to many other man-made chemicals present in the environment, pesticides are deliberately spread into the environment. They are manufactured to be harmful to specific target organisms, or groups of organisms, and their toxic properties are essential to give the pesticides a satisfactory function. Due to pesticides' toxic properties, there is an obvious risk that non-target organisms are affected, either at the application site, or due to unintentional spreading, at nearby, or even distant, areas. 
Paraquat dichloride is a non-selective contact herbicide, used in controlling pests of cultivated farmlands of rice, cotton, fruit, tea, potatoes, sugar cane and vegetable. It quickly kills a wide range of annual grasses, broad leafs, weeds and some perennial grasses when sprayed directly onto leaves. More so, the active ingredient is rapidly absorbed by clay and silt particles in the soil and does not leave any effective soil residue (Fryer, 1977). Paraquat dichloride is a wide range herbicide. Repeated applications of this herbicide is practised for weed control of weed in agricultural field and thereby, large quantities find their way into the water bodies. Chemicals like paraquat, originating from agricultural activity enter the aquatic environment through atmospheric deposition, surface run-off or leaching and frequently accumulate in soft-bottom sediments and aquatic organisms (Fryer, 1977). The toxicity of a chemical is totally dependent on the concentration of the chemical in organisms or even the concentration at the target receptor in the organism (Ayoola, 2008).

Pesticides and herbicides at high concentration are known to reduce the survival, growth and reproduction of fish, and produce many visible effects on fish (Rahman et al., 2002).

Toxicity testing of chemicals on animals has been used for a long time to detect the potential hazards posed by chemicals to man. Bioassay technique has been the cornerstone of programmes on environmental health and chemical safety (Ward and Parrish, 1982). Aquatic bioassays are necessary in water pollution control to determine whether a potential toxicant is dangerous to aquatic life and if so, to find the relationship between the toxicant concentration and its effect on aquatic animals (Olaifa et al., 2003). The application of environmental toxicology studies on non-mammalian vertebrates is rapidly expanding, and for the evaluation of the effects of noxious compounds (Ayoola, 2008).

Histopathological changes of gills such as hyperplasia and hypertrophy, epithelial lifting, aneurysm and increase in mucus secretion have been reported after the exposure of fish to a variety of noxious agents in the water, such as pesticides, phenol and heavy metal (Nowak, 1992). Also the liver is a very important organ which breaks down chemicals and as a result, liver cells are often among those that are damaged by toxic chemicals.

Effects of glyphosate herbicide on Tilapia was investigated by Ayoola (2008), filament cell proliferation, lamellar fusion, lamellar cell hyperplasia and epithelial lifting were observed. The major effects observed on the gills were Oedema, epithelial lifting, and thickening of the primary lamellar epithelium and fusion of secondary lamellae.

In view of the need for knowledge of the aquatic side-effects of Paraquat dichloride agrochemical, the objective of this study is to determine the lethal concentration and the acute toxic effect of Paraquat dichloride with emphasis on the histopathology on Clarias gariepinus.

\section{Materials and methods}

A 96 -hour short-term static bioassay was conducted using the fingerlings of Clarias gariepinus as test organisms. This was done in order to study the toxicity of Paraquat dichloride on fish, and determine allowable levels or concentrations of Paraquat dichloride for very short exposures.

\subsection{Sources and collection}

The choice of Clarias gariepinus was informed by its ability to withstand stress and its high commercial value in Nigeria. Catfish juveniles, Clariasgariepinus averaging $47.97 \mathrm{~g}$ in weight and $20.04 \mathrm{~cm}$ in length obtained from a fish farm in Lagos state, Nigeria were used.

\subsection{Acclimatization of fish}

The fish were held in $36.5 \mathrm{~cm}$ by $25 \mathrm{~cm}$ by $26 \mathrm{~cm}$, aquarium containing non-chlorinated water. The fish were allowed to acclimatize for more than one week under laboratory conditions to allow them adapt to experimental conditions $\left(27 \pm 2{ }^{\circ} \mathrm{C}\right)$. The period of acclimatization was extended beyond one week to ascertain the condition of the fish. The fish were inspected for disease conditions and general fitness. The fish were fed during the period of acclimatisation and the water was changed every four days in order to remove faecal and unconsumed feeds. Feeding was discontinued during the 96-hour test period.

\subsection{The determination of the physico-chemical parameters of the water}

The physico-chemical parameters of the water used were examined. These parameters included temperature, dissolved oxygen (D.O.) and the hydrogen ion concentration ( $\mathrm{pH}$ ). The temperature and the dissolved oxygen of the water was measured with a Model JPSJ-605 DO-Analyser, while the $\mathrm{pH}$ was measured using the HANNA HI 9813 GRO CHEK meter.

\subsection{General bioassay techniques}

The bioassay was carried out in a square glass tank. The top was covered with mesh net aided by elastic rubber 
band to prevent the fish from escaping. Each tank size of $36.5 \mathrm{~cm}$ by $25 \mathrm{~cm}$ by $26 \mathrm{~cm}$ contained sixteen fish .

After a range - finding test, the concentrations prepared for the experiment were $0 \mathrm{mg} / \mathrm{L}, 20 \mathrm{mg} / \mathrm{L}, 60 \mathrm{mg} / \mathrm{L}, 80$ $\mathrm{mg} / \mathrm{L}$ and $110 \mathrm{mg} / \mathrm{L}$, with two replicates as described by Rahman et al., (2002). The amount of Paraquat dichloride which contained the require $\mathrm{mg}$ of Paraquat was determined from the $276 \mathrm{~g} / \mathrm{L}$ of Paraquat dichloride formulation.

$$
\mathrm{y}=\frac{\mathrm{x}}{276 \mathrm{~g} / \mathrm{L}(27600 \mathrm{mg} / \mathrm{L})}
$$

$\mathrm{x}=$ concentrations $(0 \mathrm{mg} / \mathrm{L}, 20 \mathrm{mg} / \mathrm{L}, 40 \mathrm{mg} / \mathrm{L}, 60 \mathrm{mg} / \mathrm{L}, 80 \mathrm{mg} / \mathrm{L}$ and $110 \mathrm{mg} / \mathrm{L})$

$\mathrm{y}=\mathrm{ml}$ of stock to be taken

The behavioural pattern of the fish and other external changes in the body of fish were observed accordingly. Dead fish were identified by an absolute lack of movement. They were removed as soon as this was noticed, and disposed. The $\mathrm{LC}_{50}$ value of the Clarias gariepinus for $96 \mathrm{hrs}$ was calculated using the probit analysis.

\subsection{Histopathology studies}

The organs were removed and prepared for histhopathological observation. They were fixed in bouin's fluid for 24 hours, washed with 70 percent ethanol and dehydrated through a graded series of ethanol (Schalm et al, 1995, Kelly, 1979). They were embedded in paraffin,sectioned at 4-5 um thickness stained with haematoxylin and eosin and examined using light microscope and photomicrography (Keneko, 1989).

\subsection{Statistical analysis}

The dose responce of mortality were analysed by probit analysis (Finney, 1971) based on a computer programme by Ge Le PaHoure, Imperial College, London and adopted by Don-Pedro (1989), Otitoloju (2001). This was used to derive the $\mathrm{LC}_{50}, \mathrm{LC}_{95}$.

$\mathrm{LC}_{50}=$ Median lethal concentration that causes $50 \%$ mortality of exposed animals.

$\mathrm{LC}_{95}=$ Lethal concentration that causes $95 \%$ mortality of exposed animals.

\section{Results}

\subsection{The physico-chemical characteristics of the water}

The physico-chemical parameters of the water values are:

Dissolved oxygen (D.O.) $7.4 \pm 1.0 \mathrm{mg} / \mathrm{L}$,

Temperature $26.7 \pm 0.1^{\circ} \mathrm{C}$ and the $\mathrm{pH} 6.8-7.0$.

\subsection{Acute toxicity}

The results of the acute toxicity test are presented in Table 1 . The $\mathrm{LC}_{50}$ value based on probit analysis was found to be $60 \mathrm{mg} / \mathrm{L}$ for $96 \mathrm{hrs}$ of exposure to the herbicide (Fig. 1). The results obtained showed that there was no mortality of fish in the control experiment throughout the $96 \mathrm{hrs}$. There was no mortality of the fish exposed to $20 \mathrm{mg} / \mathrm{L}$. However there was $50 \%$ mortality at $60 \mathrm{mh} / \mathrm{L}$, while at $110 \mathrm{mg} / \mathrm{L}, 100 \%$ mortality was observed (Table 1).

During this study the behaviour of the control fish was normal, while the fish introduced into the different concentrates of the herbicides showed different abnormal behaviour. Abnormal behaviour such as erratic swimming, sudden quick movements and restlessness were observed in fish exposed to the chemical. At high concentration of $110 \mathrm{mg} / \mathrm{L}$, the fish became very weak and settled at the bottom. Normal colour and behavioural response was observed in the control experiment.

\subsection{Histopathological effect}

GILL: Sections through the gill showed normal cellular pattern, ranging from gill arch, gill rakers, filament, venus, sinus, cartilaginous support, pseudo-brachial lamella, ceratobrachial bone of the arch, mucous epithelium lining on the membrane and branches of the afferent and efferent arterioles, and nucleous (Fig. 2). No lesion, necrosis, pigments, malignancy, inflammation or inclusion bodies were seen. Moderate and severe areas of lesion, necrosis, malignancy, pigment and inclusion bodies were observed in fish exposed to Paraquat (Fig. 3, $4)$.

LIVER: Transverse section through the liver showed normal cellular pattern, normal central vein, space of dissect, billary epithelium, hepatic plate and hepatocytes. No lesion, necrosis, pigments, malignancy, inflammation or inclusion bodies were seen in the control (Fig. 5). There were areas of slight lesion, necrosis, 
malignancy, pigment, inclusion bodies and inflammation in the livers exposed to the herbicides (Fig 6).

\section{Discussion}

Paraquat dichloride is one of the widely used herbicides that could be persistent and mobile in soil and water, and it is known to be one of the most common terrestrial and aquatic contaminants (Cox, 1998). The present study showed that the $96 \mathrm{~h} \mathrm{LC50}$ value of Paraquat dichloride was $60 \mathrm{mg} / \mathrm{L}$ for Clarias gariepinus juveniles. The LC50 Value of this study for Clarias gariepinus juveniles is similar to the findings of Ayoola (2008). The Paraquat dichloride exerted toxic effect on the fish in the present study and toxicity increased with increased concentration. Abnormal behaviours such as incessant jumping and gulping of air, restlessness, loss of equilibrium, increase opercular acivities, surface to bottom movement, sudden quick movement and resting at the bottom observed in this study were similar to the observations of Omitoyin et. al.,(2002) and Fafioye (2001). The fish were stressed progressively with time before eventually dying. The stressful ailment of respiratory impairment due to the toxic effect of Paraquat dichloride on the gills was similar to the report of Omitoyin et al. (2006). The observed increasing state of inactivity with both increasing concentrations and exposure period agree with the report of Ayoola (2008).Swelling in the abdominal region and gas filled stomach were not observed, which is contrary to the finding of Lovely (1998) that used insecticides formulation which indicate that the effect of pesticides and herbicides are species-specific.

Water quality parameters had little variation, physicochemical parameter measured seemed to be within optimum range for fish culture as reported by Omitoyin et al. (2006) and Olaifa et al. (2003).

Moderate areas of lesion, necrosis, malignancy, pigment and inclusion bodies are noted with no obvious cellular abnormalities with area of inflammation in gills and liver of fish exposed to the herbicide as observed by Omitoyin et. al. (1999).

\section{Conclusion}

The results of the present study revealed that Paraquat dichloride is toxic to fish organs and causes histopathological changes in different organs such as gills and liver; therefore, indiscriminate use by farmers should be discouraged particularly in aquatic bodies.

\section{References}

Annune, P.A., Hbele, S.O., \& Oladimeji, A.A. (1994). Acute Toxicity of Cadmium to Juvenile of Clariasgariepinus (Tuegls) and Oreochromisniloticus (Trewavas). Journal of Environmental Science and Health, 29, 1357-1365.

Ayoola, S.O. (2002). Acute toxicity, Behavioural changes and Histopathological effect of Glyphosate on tissues (gill, liver and kidney) of Nile tilapia (Orechromis niloticus) Juvenile. Obeche Journal, 20, 96-108.

Ayoola, S.O. (2008a).Toxicity of glyphosate herbicideon Nile tilapia (Oreochromisniloticus) juvenile. African Journal of Agricultural Research, 3, 825-834.

Ayoola, S.O. (2008b). Histopathological effects ofglyphosate on juvenile African catfish (Clariasgariepinus). American-Eurasian Journal of Agricultural \& Environmental Science, 4, 362-367.

Fafioye, O.O. (2001). Lethal and sublethal effects of extract of Parkira biglobosa and Raphia vinifera on some freshwater fauna. Ph.D. Thesis, University of Ibadan, Ibadan, Nigeria. 216.

Finney, D. J. (1971). Probit Analysis, 3rd edn. Cambridge University Press, Cambridge, 20.

Fryer, J.D. (1977). Weed control Handbook edited by Make Peace GESAMP, 1, 384-389.

Kelly, W.R. (1979).Veterinary clinical diagnosis $2^{\text {nd }}$ ed. Balliere Tindall, London. pp. 266-279.

Keneko, J.J. (1989). Clinical Biochemistry of domestic animals. $4^{\text {th }}$ ed. Diego, Academic press Inc. California, $132 \mathrm{pp}$.

Lovely, F. (1998). Toxicity of three commonly used organo- phosphorus insecticides to Thai sharputi (Barbodes gonionotus) and the African catfish (Clarias garienpinus) Fry. Department of Fishieries Biology and Genetics, Bangladesh Agricultural University, Mymensigh, Bangladesh, M.Sc. Thesis, 83.

Mason, C.F. (1991). Biology of Freshwater Pollution. $2^{\text {nd }}$ Edition, Longman Scientific and Technical U.K. 351 pp.

Nowak, B. (1992). Histological changes in Gills induced by residues of Endosulfan. Journal of Aquatic toxicology, 23, 63-84.

Olaifa, F.E, Olaifa, A.K \& Lewis O.O. (2003). Toxic Stress of Lead on Clariasgariepinus (African catfish) 
Fingerlings. African Journal of Biomedical Research, 6, 101 -104.

Omitoyin, B.O., Ajani, E.K., Adeshina, B.T. \& Okuagu, C.N.F. (2006). Toxicity of Lindane (GammaHexachloro - CycloHexane) to Clariasgariepinus(Burchell 1822). World Journal of Zoology, 1, 57-63.

Omoniyi, I.A., Agbon O., \& Sodunke, S.A. (2002). Effect of lethal and sublethal concentrations of Tobacco ( Nicotiana tabaccum). Leaf Dust Extraction on weight and haemetaological changes in Clarias garienpinus (Burchell). J. Applied Sci. Environ., Man6, 37-41.

Rahman, M.Z., Hossain, Z.M., Ellah, M.F.R., \& Ahmed, G.U. (2002). Effect of Diazinon 60EC on Anabustestudineus, Chama punctatus and barbadesgomonous. Naga. The ICLARM quarterly, 25, 8-11.

Ward, G.S. \& Parrish, P.R. (1982). Manual of Methods in Aquatic environmental research. Part 6. Toxicity Tests .FAO Fisheries Technical Paper, No 185 FIRI/T185.

World Health Organization (WHO). (1991). Paraquat Health and Safety Guide. Health and Safety Guide Publication No. 51. Geneva Switzerland.

Table 1. Rate Of mortality of Juvenile Catfish Clarias garienpinus exposure To Paraquat On for 96 hrs

\begin{tabular}{|c|c|c|c|c|c|}
\hline Concentrations & $24 \mathrm{hrs}$ & $42 \mathrm{hrs}$ & $72 \mathrm{hrs}$ & $96 \mathrm{hrs}$ & Mortality \\
\hline Control & 0 & 0 & 0 & 0 & 0 \\
\hline $20 \mathrm{mg} / \mathrm{L}$ & 0 & 1 & 1 & 1 & 1 \\
\hline $40 \mathrm{mg} / \mathrm{L}$ & 0 & 2 & 2 & 2 & 2 \\
\hline $60 \mathrm{mg} / \mathrm{L}$ & 1 & 3 & 4 & 8 & 8 \\
\hline $80 \mathrm{mg} / \mathrm{L}$ & 1 & 4 & 5 & 10 & 10 \\
\hline $110 \mathrm{mg} / \mathrm{L}$ & 2 & 11 & 16 & 16 & 16 \\
\hline
\end{tabular}

Table 2. Calculated log dose and probit values

\begin{tabular}{|l|c|c|c|c|}
\hline Concentration & Logdose & Mortality & Percentage & Probit \\
\hline $20 \mathrm{mg} / \mathrm{L}$ & 1.30103 & 1 & 6.25 & 3.465879 \\
\hline $40 \mathrm{mg} / \mathrm{L}$ & 1.60206 & 2 & 12.5 & 3.849651 \\
\hline $60 \mathrm{mg} / \mathrm{L}$ & 1.778151 & 8 & 50 & 5 \\
\hline $80 \mathrm{mg} / \mathrm{L}$ & 1.90309 & 10 & 62.5 & 5.318639 \\
\hline
\end{tabular}

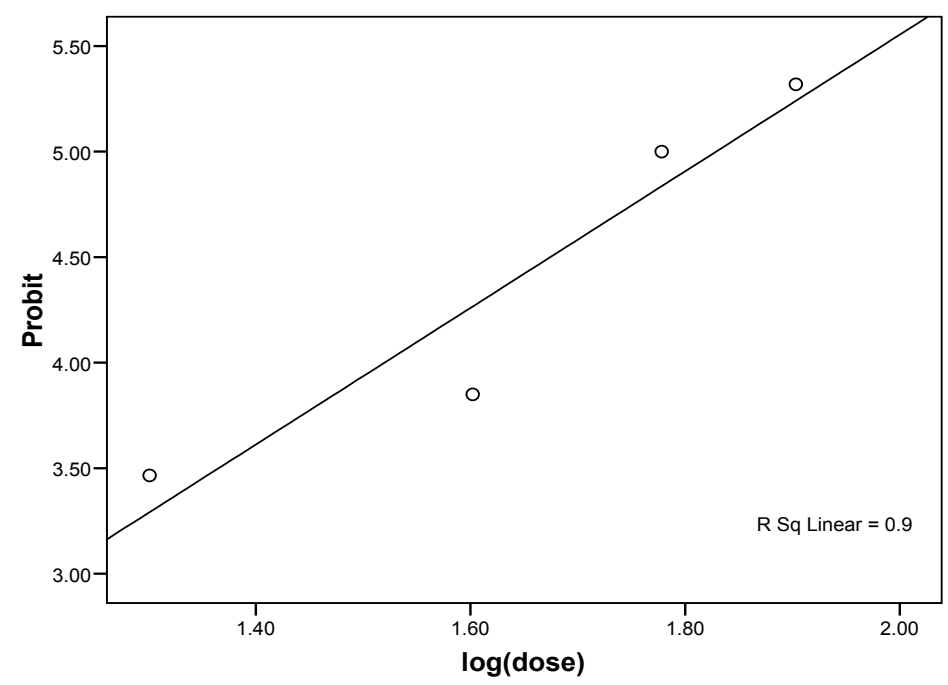

Figure 1. Linear relationship between Probit response and log concentration of Paraquat dichloride on juvenile Clarias garienpinus. 


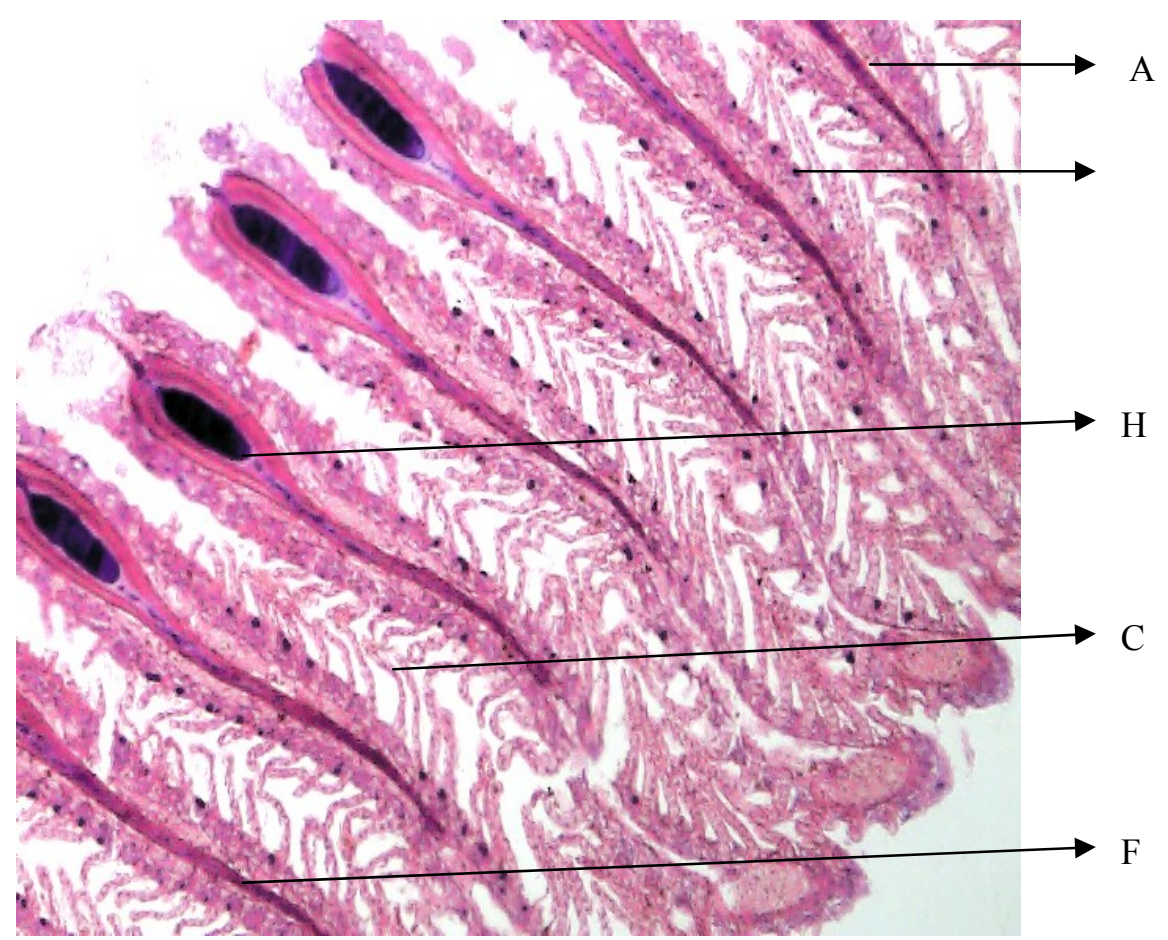

Figure 2. Section through the gills shows normal cellular pattern, ranging from (A), gill arch; (C)-filament; (F), cartilaginous support; $(\mathrm{H})$, ceratobrachial bone of the arch. No lesion, no necrosis, no pigments, no malignancy, no inflammation and no inclusion bodies seen.

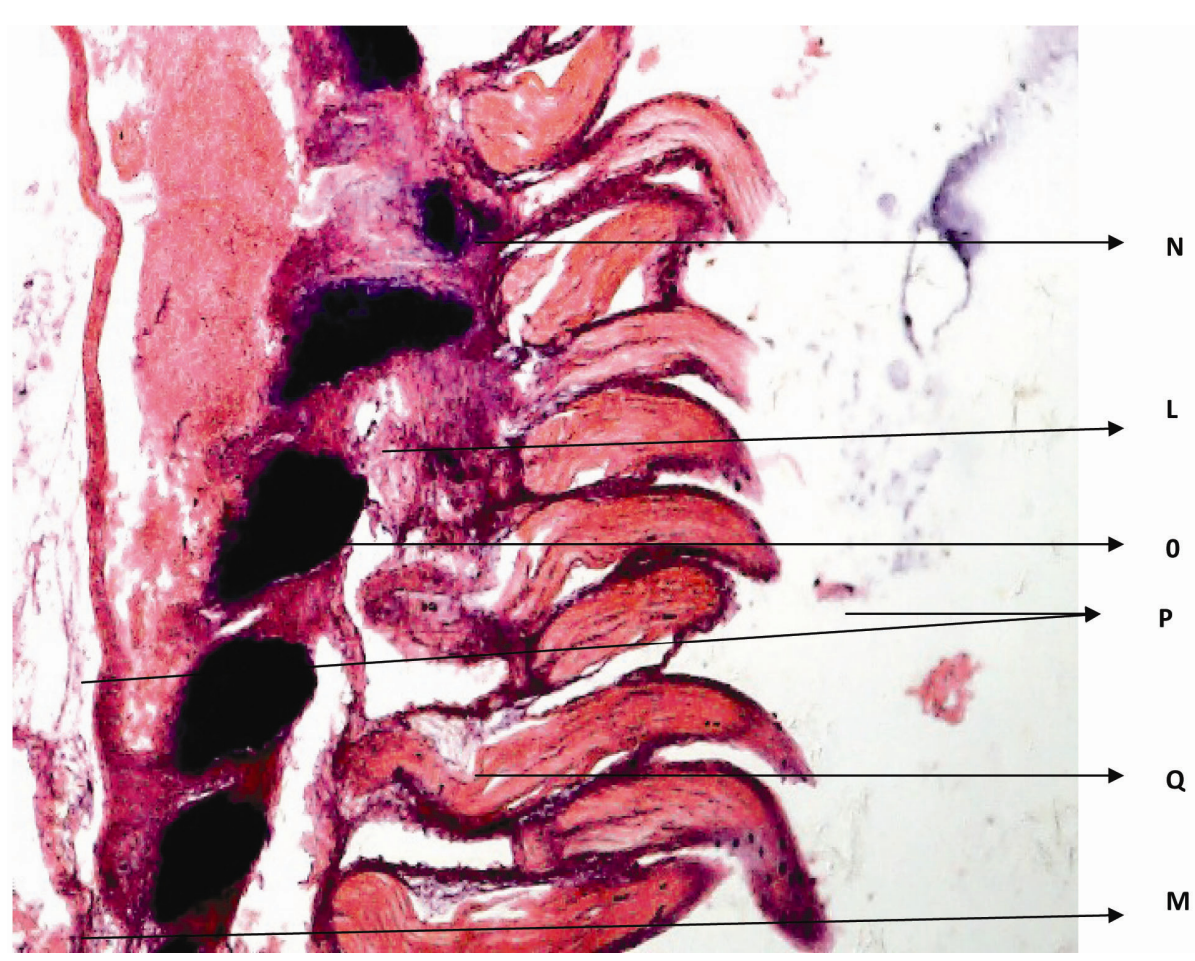

Figure 3. Histological section through the exposed Gills -1: Severe areas of (L) lesion, (N) necrosis, (M) malignancy, $(\mathrm{O})$ pigment and $(\mathrm{P})$ inclusion bodies were noted with obvious cellular abnormalities with areas of (Q) inflammation. 


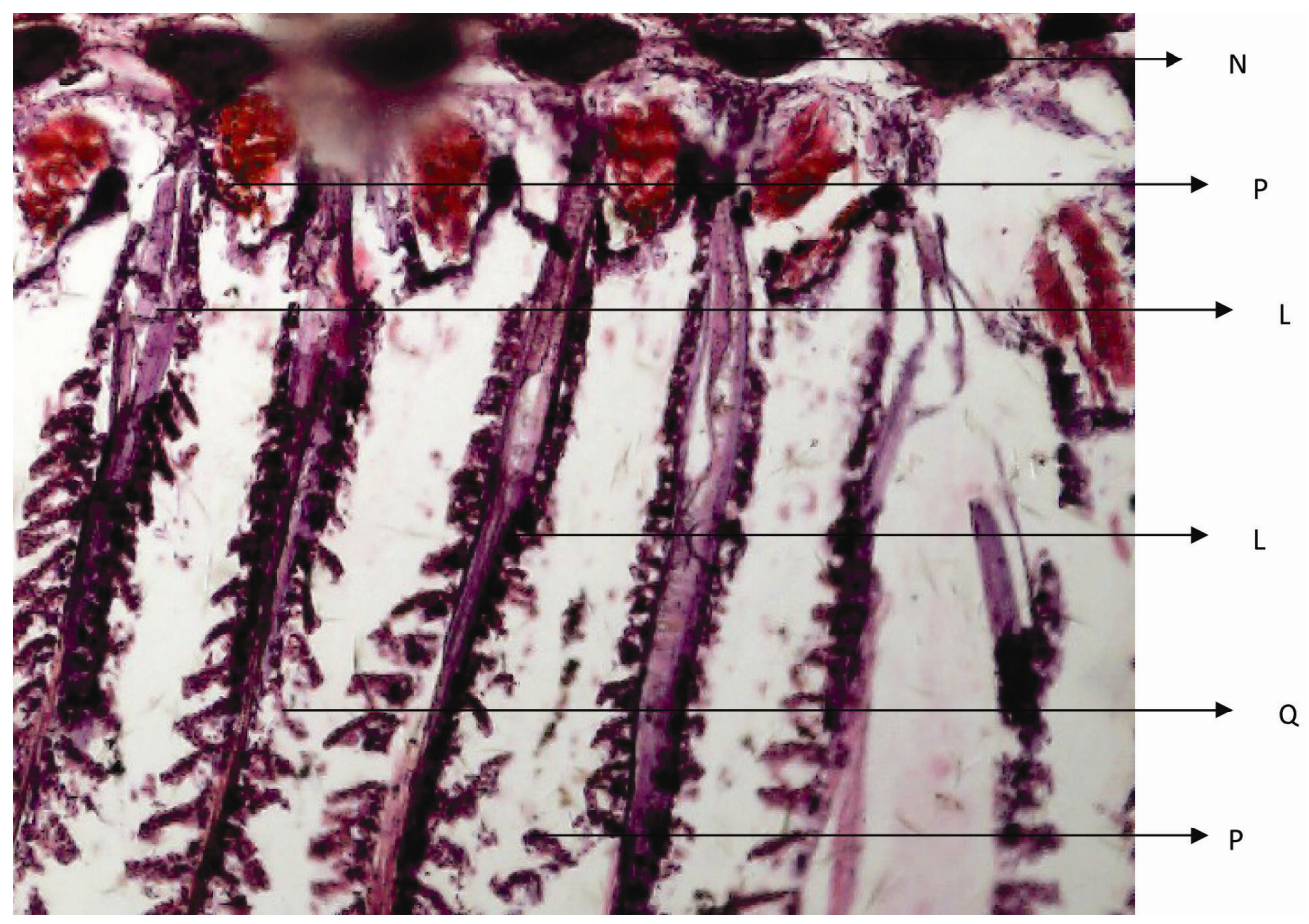

Figure 4. Histological section through the exposed Gill-: Severe areas of (L) lesion, (N) necrosis, $(M)$ malignancy, $(\mathrm{O})$ pigment and $(\mathrm{P})$ inclusion bodies are noted with obvious cellular abnormalities with area of $(\mathrm{Q})$ inflammation.

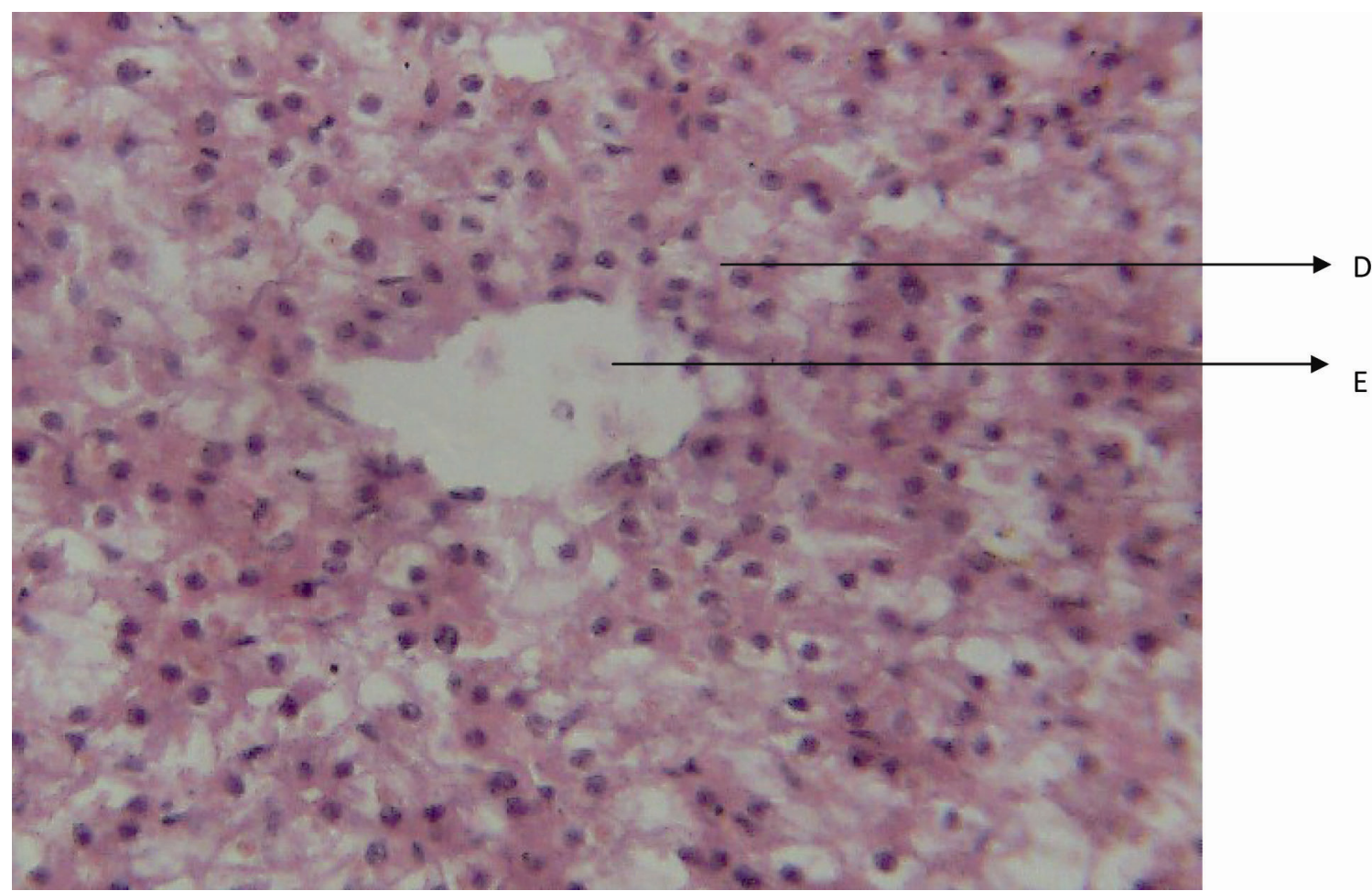

Figure 5. Histological section through the Control liver : Transverse section through the liver shows normal cellular pattern, (D) normal central vein, (E) space of dissect. No lesion, no necrosis, no pigments, no malignancy, no inflammation and inclusion bodies seen. 


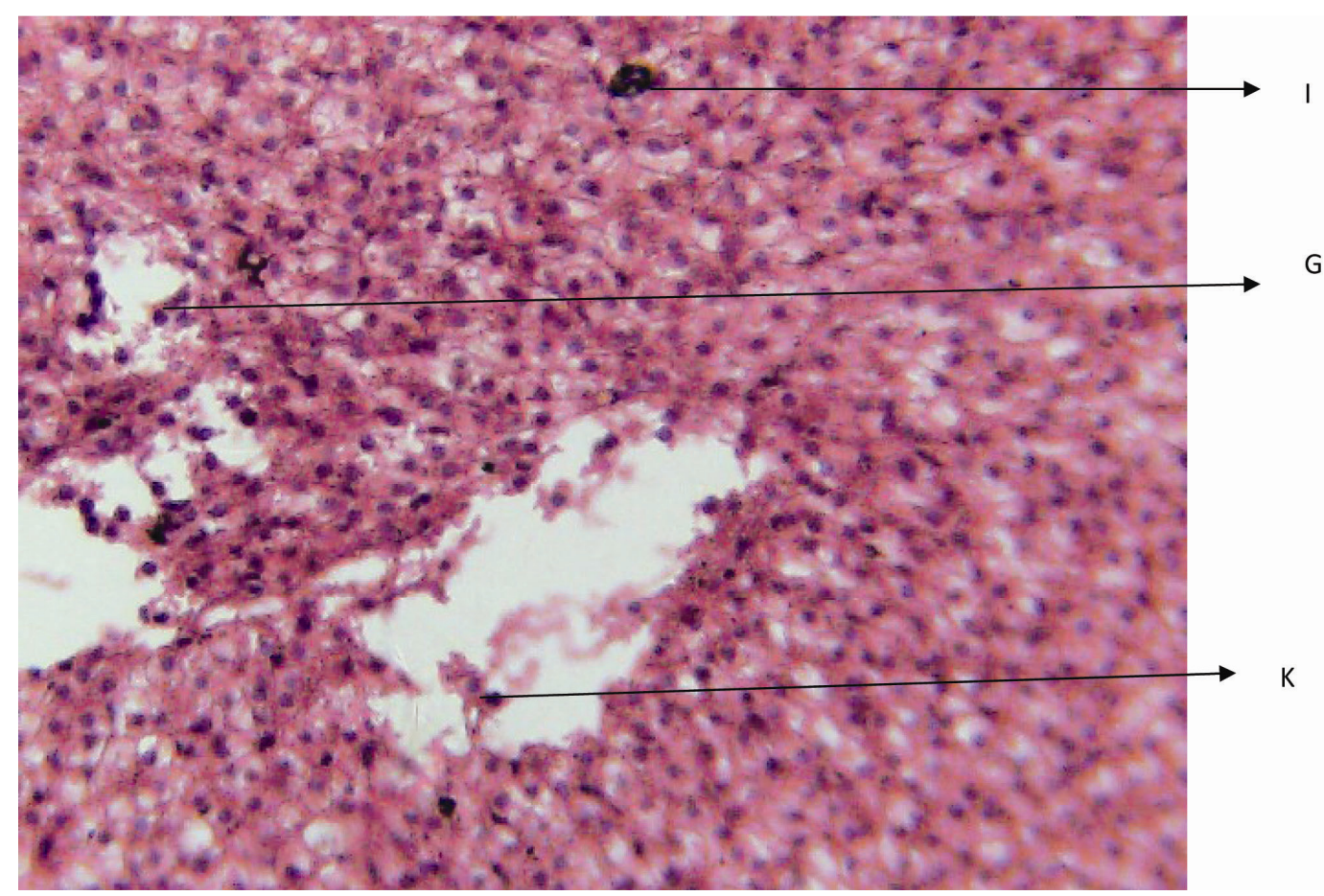

Figure 6. Histological section through the Liver-Exposed: Moderate area of, (G) necrosis, (I) pigment and (J) inclusion bodies are noted with obvious cellular abnormalities with area of $(\mathrm{K})$ inflammation. 